\title{
Saccharothrix: a New Genus of the Actinomycetales Related to Nocardiopsis
}

\author{
D. P. LABEDA, ${ }^{1} \dagger$ R. T. TESTA, ${ }^{1 *}$ M. P. LECHEVALIER, ${ }^{2}$ AND H. A. LECHEVALIER ${ }^{2}$ \\ Medical Research Division, American Cyanamid Company, Pearl River, New York 10965, ${ }^{1}$ and Waksman Institute of \\ Microbiology, Rutgers, The State University, New Brunswick, New Jersey $08903^{2}$
}

\begin{abstract}
A species of the new genus Saccharothrix is described under the name Saccharothrix australiensis sp. nov. This aerobic genus is characterized by fragmentation of both the vegetative and aerial mycelia into ovoid elements and the following novel cell chemistry: type III cell wall (meso-diaminopimelic acid present); galactose and rhamnose present as characteristic whole-cell sugars; absence of nocardomycolic acids; and type PII phospholipid pattern. The guanine-plus-cytosine content of the deoxyribonucleic acid is $73 \mathrm{~mol} \%$. The type strain of Saccharothrix australiensis is strain LL-BM782Ce82 (= ATCC $31947=$ NRRL 11239).
\end{abstract}

Nocardioform microorganisms, as described by Prauser (19), are bacteria included in the Actinomycetales which reproduce by fragmentation of their hyphae into irregular to rodlike coccoid elements. In recent years several new nocardioform taxa have been described, such as Nocardiodes Prauser (19) and Nocardiopsis Meyer (17). In this paper we describe the type strain of a new nocardioform genus. This strain was isolated from a soil sample collected in Australia and was found to produce a complex of novel beta-lysinecontaining aminoglycoside antibiotics, including BM782 alpha 1, BM782 alpha 2, and BM782 alpha 1a, which are the subject of a United States patent (Tresner et al., U.S. patent 4,234,717, Nov. 1980) assigned to American Cyanamid Co., Pearl River, N.Y. The cell chemistry of this microorganism differs significantly from the cell chemistry of previously described genera of actinomycetes. We propose to include this strain in the new genus Saccharothrix, the type species of which is Saccharothrix australiensis. A culture of the type strain, strain LL-BM782Ce82, has been deposited with the American Type Culture Collection (ATCC), Rockville, Md., as strain ATCC 31947 and with the Agricultural Research Service Culture Collection at the U.S. Department of Agriculture Northern Regional Research Center, Peoria, Ill., as strain NRRL 11239.

\section{MATERIALS AND METHODS}

Bacterial strain and culture conditions. Strain LL$\mathrm{BM} 782 \mathrm{Ce} 82^{\mathrm{T}}$ ( $\mathrm{T}=$ type strain) was a strain isolated from a soil sample collected in Australia. Stock cultures were grown on yeast extract-malt extract agar (ISP-2 medium) or ATCC medium 172 (1). The other media used in this study were those recommended for use in the International Streptomyces Project (23) and included oatmeal agar, inorganic salts-starch agar, glucose-asparagine agar, and yeast extractmalt extract agar.

Physiological tests. The media and tests used to evaluate the physiological properties were the media and tests described by Gordon et al. (9).

Cell chemistry. Characteristic whole-cell chemistry was analyzed by using the methods of Becker et al. $(2,3)$ and Lechevalier et al. and Lechevalier $(12,13)$, and phospholipid composition was determined by the method of Lechevalier et al. $(14,15)$. Menaquinones were extracted, separated, and

\footnotetext{
* Corresponding author.

† Present address: Northern Regional Research Center, U.S. Department of Agriculture, Peoria, IL 61604.
}

purified by using the procedures of Collins et al. $(5,6)$; they were identified from the masses of their molecular ions by electron impact mass spectroscopy with a Varian MAT model $\mathrm{CH}-7$ unit, using direct insertion, an ionizing voltage of $70 \mathrm{eV}$, and an inlet temperature of $250^{\circ} \mathrm{C}$.

DNA isolation and characterization. Deoxyribonucleic acid (DNA) was extracted and purified by the method of Marmur (16). The guanine-plus-cytosine content of the purified DNA was estimated by the buoyant density method (20). The buoyant density of the DNA was measured by $\mathrm{CsCl}$ density gradient centrifugation in a Beckman model E ultracentrifuge. The reference DNA used was from Tilletia caries NRRL Y-12807; this DNA had a buoyant density in CsCl of $1.71567 \mathrm{~g} / \mathrm{cm}^{3}$, as determined by comparison with Micrococcus luteus DNA (Sigma Chemical Co., St. Louis, Mo.).

Electron microscopy. Samples for scanning electron microscopy were prepared from cut agar blocks from colonial growth, which were fixed overnight with osmium tetroxide vapors. The blocks were trimmed and postfixed for $1 \mathrm{~h}$ by immersion in $1 \%$ osmium tetroxide in $0.1 \mathrm{M}$ cacodylate buffer ( $\mathrm{pH}$ 7.3). The blocks were washed in cacodylate buffer, dehydrated through a graded acetone series, and then critical-point dried from liquid carbon dioxide. The dried colonies were then mounted on aluminum stubs with colloidal silver paste and sputter coated with approximately 12.5 nm of gold-palladium. The samples were observed by using a Hitachi model S-500 scanning electron microscope operating at $20 \mathrm{keV}$.

\section{RESULTS}

Micromorphology. Both the vegetative and aerial mycelia of $S$. australiensis were composed of hyphae that fragmented into coccoid elements approximately 0.5 to 0.7 by 0.6 to $1.5 \mu \mathrm{m}$ (Fig. 1 and 2). Figure 1 shows a 28-day culture on NZ-amine-starch-glucose agar (ATCC medium 172), in which all of the vegetative mycelium has fragmented. Figure 2 shows a 14-day culture on the same medium, in which the aerial hyphae are just beginning to fragment. The morphological relationship between this culture and Nocardiopsis is evident by comparing Fig. 3, which shows a 14-day culture of Nocardiopsis dassonvillei on ATCC medium 172, with Fig. 2. The "zig-zag" morphology of Nocardiopsis hyphae observed just before septation of spores is not generally observed in $S$. australiensis.

Gross colonial morphology. A description of the colonial morphology of $S$. australiensis is given in Table 1 . The vegetative mycelium on most media is brownish to grayish 


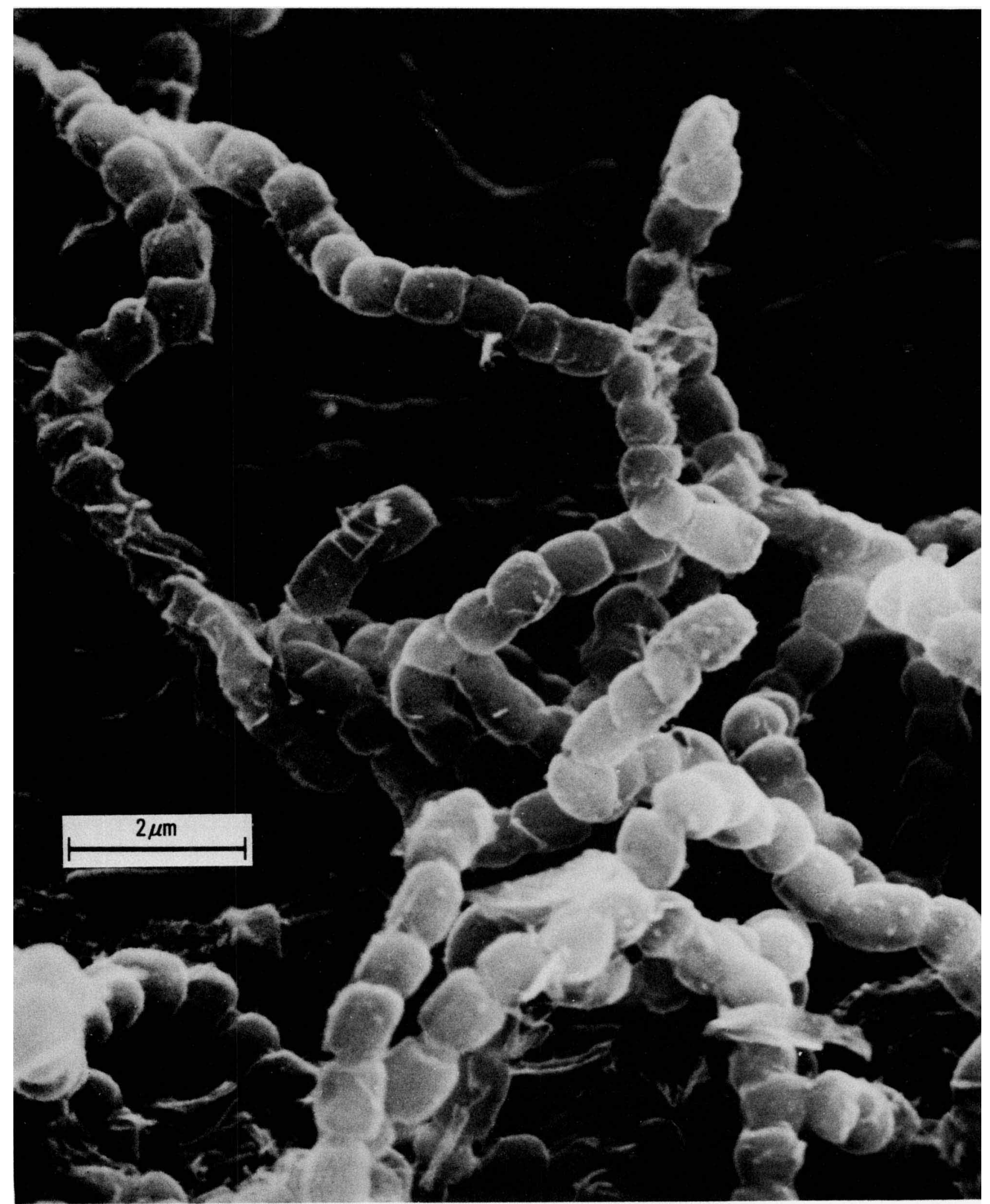

FIG. 1. Scanning electron micrograph of a 28-day culture of S. australiensis on ATCC medium 172. Note that the vegetative mycelium has totally fragmented into coccoid elements. 


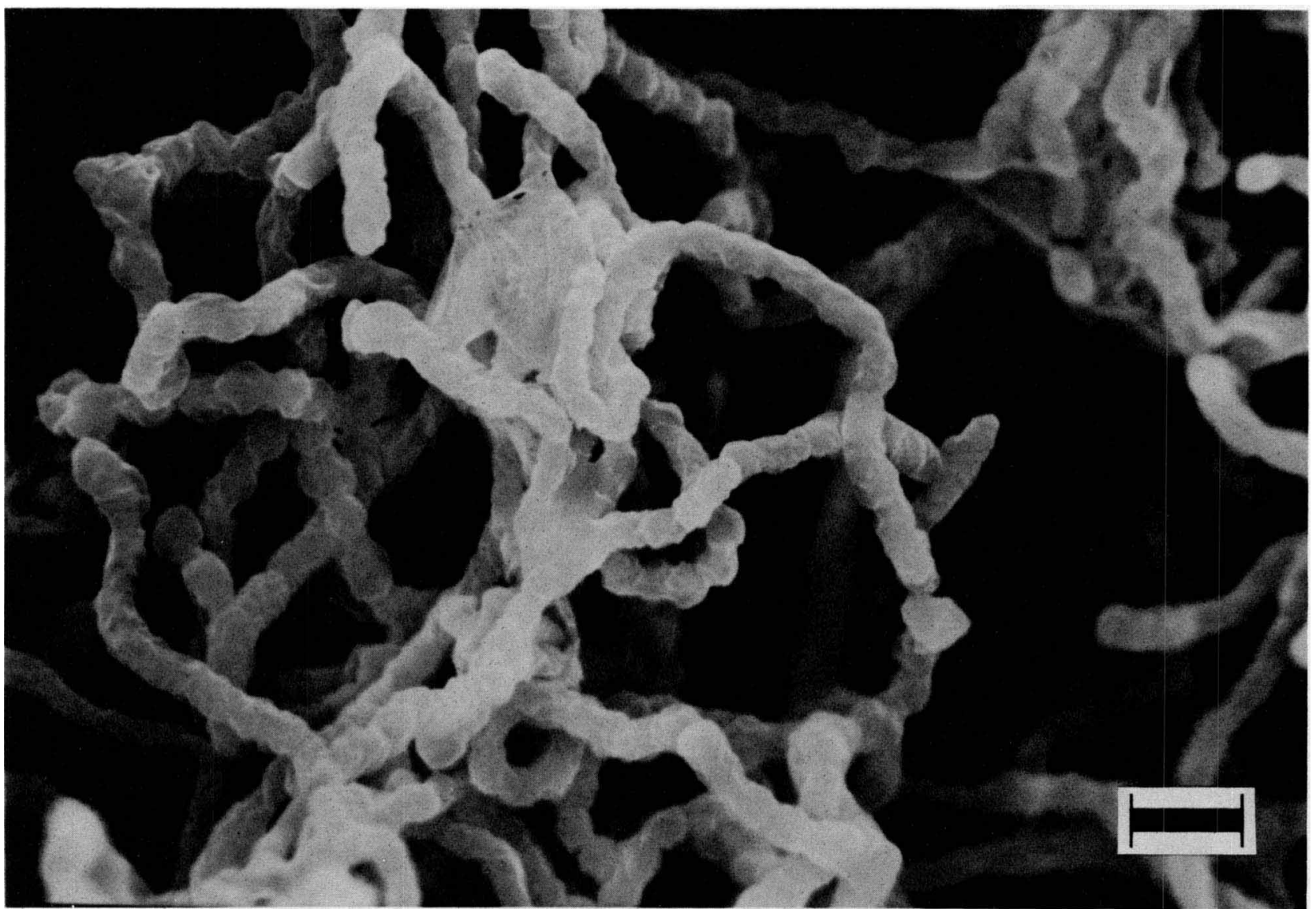

FIG. 2. Scanning electron micrograph of a 14-day culture of $S$. australiensis on ATCC medium 172. Note the fragmentation of the aerial mycelium into spores similar to those of Nocardiopsis dassonvillei (see Fig. 3). Bar indicates $2 \mu \mathrm{m}$.

yellow. The aerial mycelium, when produced in significant quantity, is yellowish white to yellowish gray.

Cell chemistry. The cell chemistry of $S$. australiensis is summarized in Table 2. The presence of galactose and rhamnose as whole-cell sugars has taxonomic significance. $S$. australiensis contained phospholipids of the type PII pattern; that is, it contained phosphatidylethanolamine as the characteristic phospholipid. Nocardomycolic acids were not present. The predominant menaquinones present in cells of $S$. australiensis were MK-9(H4) and MK-10(H4), with traces of MK-9(H6), MK-9(H8), and MK-10(H8). The guanine-plus-cytosine content of DNA extracted from $S$. australiensis was $73 \mathrm{~mol} \%$.
Physiology. Apparently due to its inability to grow on ammonium as a sole nitrogen source, $S$. australiensis did not utilize any of the carbohydrates tested with ISP-9 basal carbohydrate test medium. Using the physiological tests of Gordon et al. (9), we observed the following: casein, gelatin, and starch were hydrolyzed; nitrate was reduced; growth took place in lysozyme broth; acetate, DL-malate, propionate, pyruvate, and succinate were utilized as sole carbon sources; lactate results were variable. Acid was produced from cellobiose, dextrin, erythritol, fructose, glucose, glycerol, maltose, mannose, sorbitol, and trehalose. The temperature range for growth was 10 to $45^{\circ} \mathrm{C}$, and no growth was observed at $53^{\circ} \mathrm{C}$. The optimum temperature for growth was

TABLE 1. Morphological characteristics of $S$. australiensis LL-BM782Ce82 ${ }^{\mathrm{T}}$ on ISP media ${ }^{a}$

\begin{tabular}{lll}
\hline \multicolumn{1}{c}{ Medium } & \multicolumn{1}{c}{ Aerial mycelium ${ }^{b}$} & \multicolumn{1}{c}{ Vegetative mycelium $^{b}$} \\
\hline Oatmeal & Sparse, white & Colorless, flat colonies \\
Inorganic salts-starch & Sparse, white & Colorless, flat colonies \\
Glucose-asparagine & Fair amount of off-white growth with & Light greenish beige to olive tan, \\
& a slight greenish yellow cast & slightly raised colonies (ISCC-NBS \\
& (ISCC-NBS 92, yellowish white) & 91, dark grayish yellow) \\
Yeast extract-malt extract & Good amount of light brownish gray & Dark brown, slightly raised colonies \\
& to off-white growth (ISCC-NBS 93, & (ISCC-NBS 78, dark yellowish \\
& yellowish gray) & brown) \\
\hline
\end{tabular}

\footnotetext{
a See reference 23 .

${ }^{b}$ Inter-Society Color Council-National Bureau of Standards (ISCC-NBS) color designations were determined by using reference 10a.
} 


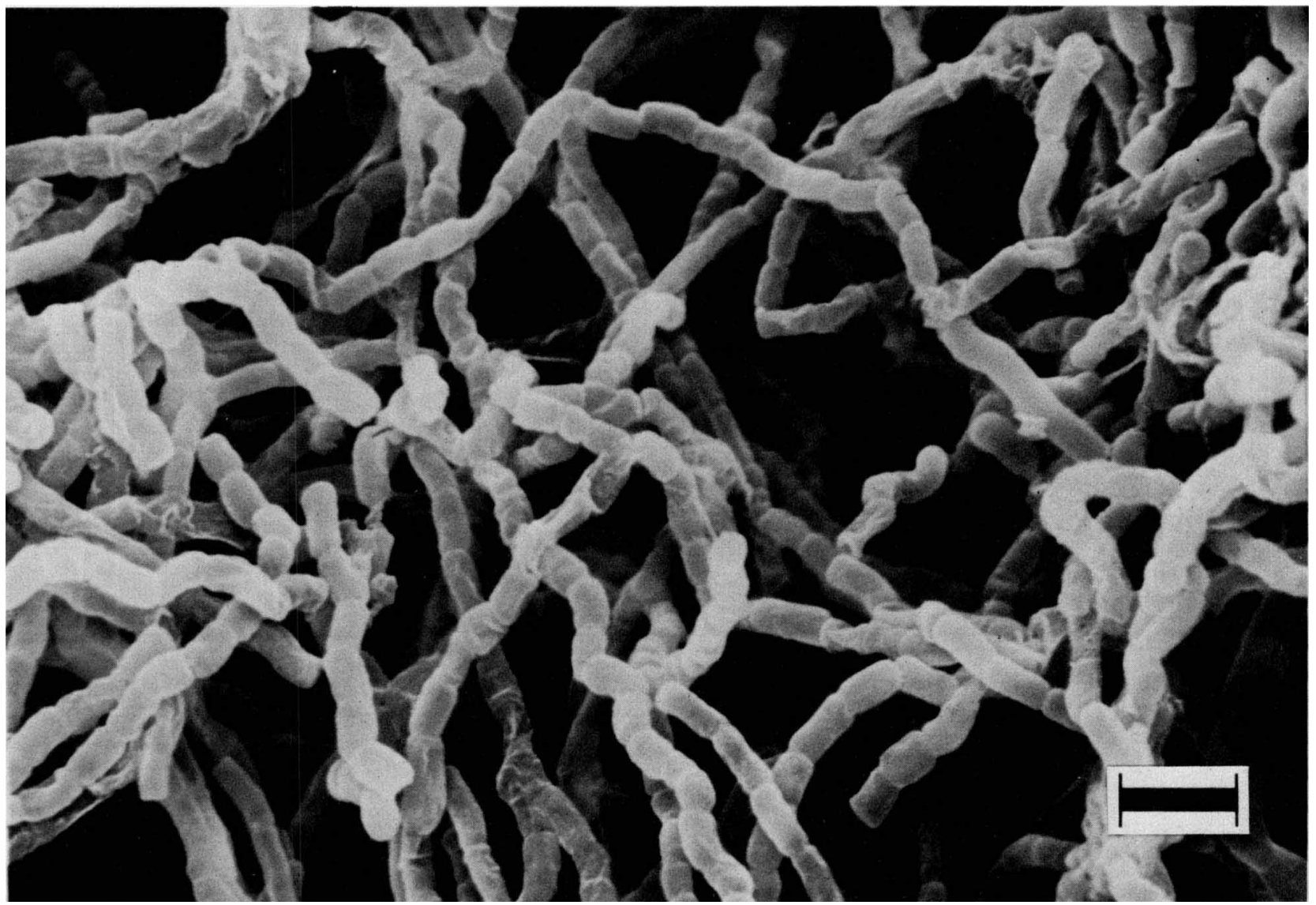

FIG. 3. Scanning electron micrograph of a 14-day culture of Nocardiopsis dassonvillei NRRL-B16089 on ATCC medium 172. Bar indicates $2 \mu \mathrm{m}$.

$30^{\circ} \mathrm{C}$. A physiological comparison of $S$. australiensis with other actinomycetes having type III cell walls is shown in Table 3.

\section{DISCUSSION}

The recognized genera of the Actinomycetales that form chains of conidia and are known to have a type III cell wall composition include Actinomadura, Actinosynnema, Nocardiopsis, Streptoalloteichus, and Streptosporangium. Actinosynnema and Streptoalloteichus can be excluded from consideration as the appropriate genus even though they have similar whole-cell sugar patterns (i.e., galactose and rhamnose), since members of these genera form motile spores ( 10 , $24)$, which were not observed in Saccharothrix. Streptosporangium is likewise excluded from consideration on morphological grounds since all of its species form sporangia (4), whereas $S$. australiensis does not. Morphologically, S. australiensis is much more closely related to the genera Nocardiopsis and Actinomadura $(7-9,11,17,21)$, and, in fact, the closest taxon from a physiological point of view is Actinomadura pelletieri. The genus Actinomadura, as currently described, contains strains that form relatively short chains of spores and have madurose as the characteristic whole-cell sugar (type B). Since strain LL-BM782Ce82 ${ }^{\mathrm{T}}$ has very long chains of spores and its whole cell hydrolysates lack madurose, it cannot be considered for inclusion in this genus. Although S. australiensis resembles Nocardiopsis species morphologically, it is different from all described Nocardiopsis species physiologically, especially regarding its inability to grow on ISP-9 medium with any carbon source tested, as well as in cell chemical composition. The presence of galactose and rhamnose as a whole-cell sugar pattern has taxonomic significance, since a number of nocardioform actinomycetes have this cell chemistry, including "Nocardia aerocolonigenes" (22) and Nocardiopsis mutabilis Shearer (21). Strains having this whole-cell sugar pattern have been observed to have either a PII or PIV phospholipid pattern. At this time it appears that only the PII phospholipid pattern should be included in the definition of the new genus Saccharothrix, since there are insufficient data at this time to warrant inclusion of strains having a PIV phospholipid pattern in the new genus. Further studies are in progress to clarify this situation.

Descriptions of the genus Saccharothrix and the type species Saccharothrix australiensis are given below.

Saccharothrix gen. nov. Saccharothrix (Sac.' cha. ro. thrix. Gr. neut. noun sacchar sugar; Gr. fem. noun thrix hair; Saccharothrix sugar-containing hair). Branching vegetative mycelium (diameter, approximately $0.5 \mu \mathrm{m}$ ) and, on some media, aerial mycelium are produced. Both vegetative and aerial hyphae fragment into ovoid elements. Gram positive. Lysozyme resistant. Catalase positive and aerobic. The cell wall is type III (meso-diaminopimelic acid) and has a wholecell sugar pattern consisting of major amounts of galactose and rhamnose. Type PII phospholipid pattern. No nocardomycolic acids are present in the cells. The guanine-pluscytosine content of the DNA is $73 \mathrm{~mol} \%$. The type species is Saccharothrix australiensis. 
TABLE 2. Chemical composition of $S$. australiensis LLBM782Ce82 $2^{\mathrm{T} a}$

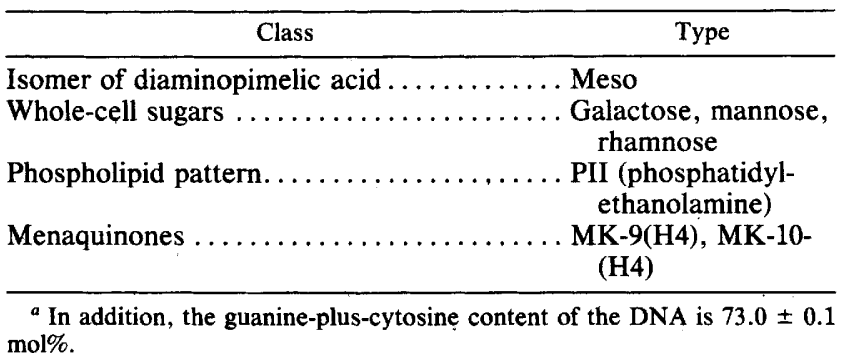

Saccharothrix australiensis sp. nov. Saccharothrix australiensis (aus. tral. i. en' sis. L. adj. australiensis referring to the location of the soil sample from which the organism was first isolated). Brownish to grayish yellow substrate mycelium with yellowish white to yellowish gray aerial mycelium (particularly on yeast extract-malt extract agar). Brownish soluble pigment produced on several media. Casein, tyrosine, gelatin, and esculin hydrolyzed. Nitrate reduced to nitrite. Acid produced from cellobiose, dextrin, erythritol, fructose, glucose, glycerol, maltose, mannose, sorbitol, and trehalose. Nitrate not used as a sole nitrogen source. Acetate, DL-malate, propionate, pyruvate, and succinate used as sole carbon sources. Temperature range for growth, 10 to

TABLE 3. Physiological comparison of $S$. australiensis with other actinomycetes having type III cell walls ${ }^{a}$

\begin{tabular}{|c|c|c|c|c|c|c|}
\hline Characteristic & $\begin{array}{c}\text { Saccharothrix } \\
\text { australiensis }\end{array}$ & $\begin{array}{c}\text { Actinomadura } \\
\text { madurae }^{b}\end{array}$ & $\begin{array}{c}\text { Actinomadura } \\
\text { pelletier }^{b}\end{array}$ & $\begin{array}{c}\text { Nocardia } \\
\text { aerocolonigenes }\end{array}$ & $\begin{array}{l}\text { Nocardiopsis } \\
\text { dassonvillei }^{b}\end{array}$ & $\begin{array}{c}\text { Nocardiopsis } \\
\text { mutabilis }^{c}\end{array}$ \\
\hline \multicolumn{7}{|l|}{ Dissimilation of: } \\
\hline Xanthine & $-{ }^{d}$ & - & - & - & + & - \\
\hline Hypoxanthine & - & + & V & + & + & + \\
\hline Adenine & - & - & - & - & + & - \\
\hline Potato starch & - & + & - & + & + & + \\
\hline Urea & - & - & - & + & V & - \\
\hline Esculin & + & + & - & + & $\mathrm{V}$ & + \\
\hline \multicolumn{7}{|l|}{ Production of: } \\
\hline Phosphatase & - & ND & ND & + & ND & ND \\
\hline Nitrate reductase & + & + & + & V & + & + \\
\hline Growth on lysozyme broth & + & - & - & + & - & + \\
\hline \multicolumn{7}{|l|}{ Alkaline reaction on: } \\
\hline Citrate & - & V & - & + & + & + \\
\hline Lactate & $\mathrm{V}$ & ND & ND & + & + & + \\
\hline Malate & + & + & V & + & + & + \\
\hline Oxalate & - & ND & ND & + & - & - \\
\hline Succinate & + & V & - & + & + & + \\
\hline \multicolumn{7}{|l|}{ Acid from: } \\
\hline Adonitol & - & + & - & V & - & - \\
\hline Arabinose & - & + & - & + & $\mathrm{V}$ & + \\
\hline Cellobiose & + & + & - & + & ND & + \\
\hline Dextrin & + & ND & ND & + & ND & + \\
\hline Erythritol & + & - & - & - & - & - \\
\hline Fructose & + & + & + & + & + & + \\
\hline Inositol & - & V & - & + & - & + \\
\hline Lactose & - & V & - & + & - & + \\
\hline Maltose & $+(w)$ & V & - & + & + & + \\
\hline Mannitol & - & + & - & V & + & - \\
\hline Mannose & $+(w)$ & + & - & + & + & + \\
\hline Melibiose & - & - & - & + & - & + \\
\hline$\alpha$-Methyl-D-glucoside & - & - & - & - & - & + \\
\hline Raffinose & - & - & - & $\mathrm{V}$ & - & + \\
\hline Rhamnose & - & + & - & V & V & - \\
\hline Salicin & - & ND & ND & + & ND & + \\
\hline Sorbitol & + & - & - & - & - & - \\
\hline Sucrose & - & ND & ND & + & ND & ND \\
\hline Trehalose & + & + & + & + & $\mathrm{V}$ & + \\
\hline Xylose & - & + & - & + & + & + \\
\hline$\beta$-Methyl-D-xyloside & - & ND & ND & - & ND & ND \\
\hline \multicolumn{7}{|l|}{ Growth at: } \\
\hline $10^{\circ} \mathrm{C}$ & + & - & - & + & _- & _- \\
\hline $45^{\circ} \mathrm{C}$ & + & V & $\mathrm{V}$ & - & - & + \\
\hline
\end{tabular}

${ }^{a}$ The tests described by Gordon et al. (9) were used.

${ }^{b}$ Data from reference 18 .

' Data from reference 21.

${ }^{d}+$, Positive; - , negative; V, variable; ND, no data; $\mathrm{w}$, weak. 
$45^{\circ} \mathrm{C}$. Isolated from soil. The type strain of $S$. australiensis is strain LL-BM782Ce82 (= ATCC 31947 = NRRL 11239).

\section{ACKNOWLEDGMENTS}

We express appreciation to $M$. Siegel for the mass spectral analysis of menaquinone fractions and to $C$. Robnett and $C$. Kurtzman for the DNA analysis.

\section{LITERATURE CITED}

1. American Type Culture Collection. 1982. Catalog of strains I, 15th ed. American Type Culture Collection, Rockville, Md.

2. Becker, B., M. P. Lechevalier, R. E. Gordon, and H. A. Lechevalier. 1964. Rapid differentiation between Nocardia and Streptomyces by paper chromatography of whole cell hydrolysates. Appl. Microbiol. 12:421-423.

3. Becker, B., M. P. Lechevalier, and H. A. Lechevalier. 1965. Chemical composition of cell-wall preparations from strains of various form-genera of aerobic actinomycetes. Appl. Microbiol. 13:236-243.

4. Buchanan, R. E., and N. E. Gibbons (ed.). 1974. Bergey's manual of determinative bacteriology, 8th ed. The Williams \& Wilkins Co., Baltimore,

5. Collins, M. D., T. Pirouz, M. Goodfellow, and D. E. Minnikin. 1977. Distribution of menaquinones in actinomycetes and corynebacteria. J. Gen. Microbiol. 100:221-230.

6. Collins, M. D., H. N. Shah, and D. E. Minnikin. 1980. A note on the separation of natural mixtures of bacterial menaquinones using reverse phase thin-layer chromatography. J. Appl. Bacteriol. 48:277-282.

7. Goodfellow, M., G. Alderson, and J. Lacey. 1979. Numerical taxonomy of Actinomadura and related actinomycetes. J. Gen. Microbiol. 112:95-111.

8. Gordon, R. E., and A. C. Horan. 1968. Nocardia dassonvillei, a macroscopic replica of Streptomyces griseus. J. Gen. Microbiol. 50:235-240.

9. Gordon, R. E., S. K. Mishra, and D. A. Barnett. 1978. Some bits and pieces of the genus Nocardia: $N$. carnea, $N$. vaccinii, $N$. transvalensis, $N$. orientalis, and $N$. aerocolonigenes. J. Gen. Microbiol. 109:69-78.

10. Hasegawa, T., M. P. Lechevalier, and H. A. Lechevalier. 1978. New genus of the Actinomycetales: Actinosynnema gen. nov. Int. J. Syst. Bacteriol. 28:304-310.

10a.Kelly, K. L., and D. B. Judd. 1976. Color universal language and dictionary of names. NBS special publication 440. U.S. Department of Commerce, National Bureau of Standards, Washington, D.C.

11. Lacey, J., M. Goodfellow, and G. Alderson. 1978. The genus Actinomadura Lechevalier and Lechevalier, p. 107-117. In M. Modarski, W. Kurylowicz, and J. Jeljaszewicz (ed.), Nocardia and Streptomyces. G. Fischer Verlag, New York.

12. Lechevalier, H. A., M. P. Lechevalier, and N. N. Gerber. 1971. Chemical composition as a criterion in the classification of actinomycetes. Adv. Appl. Microbiol. 14:47-72.

13. Lechevalier, M. P. 1968. Identification of aerobic actinomycetes of clinical importance. J. Lab. Clin. Med. 71:934-944.

14. Lechevalier, M. P., C. DeBievre, and H. A. Lechevalier. 1977. Chemotaxonomy of aerobic actinomycetes: phospholipid composition. Biochem. Syst. Ecol. 5:249-260.

15. Lechevalier, M. P., A. C. Horan, and H. A. Lechevalier. 1971 Lipid composition in the classification of nocardiae and mycobacteria. J. Bacteriol. 105:313-318.

16. Marmur, J. 1961. A procedure for the isolation of deoxyribonucleic acid from microorganisms. J. Mol. Biol. 3:208-218.

17. Meyer, J. 1976. Nocardiopsis, a new genus of the order Actinomycetales. Int. J. Syst. Bacteriol. 26:487-493.

18. Mishra, S. K., R. E. Gordon, and D. A. Barnett. 1980. Identifcation of nocardiae and streptomycetes of medical importance. J. Clin. Microbiol. 11:728-736.

19. Prauser, H. 1976. New nocardioform organisms and their relationships, p. 193-207. In T. Arai (ed.), Actinomycetes: the boundary microorganisms. University Park Press, Baltimore.

20. Schildkraut, C. L., J. Marmur, and P. Doty. 1962. Determination of the base composition of deoxyribonucleic acid from its buoyant density in CsCl. J. Mol. Biol. 4:430-443.

21. Shearer, M. C., P. M. Colman, and C. H. Nash III. 1983. Nocardiopsis mutabilis, a new species of nocardioform bacteria isolated from soil. Int. J. Syst. Bacteriol. 33:369-374.

22. Shinobu, R., and M. Kawato. 1976. On Streptomyces aerocolonigenes, sp. nov., forming the secondary colonies on the aerial mycelia. Bot. Mag. 73:212-216.

23. Shirling, E. B., and D. Gottlieb. 1966. Methods for characterization of Streptomyces species. Int. J. Syst. Bacteriol. 16:313340 .

24. Tomita, K., Y. Uenoyama, K. Numata, T. Sasahira, Y. Hoshino, K. Fujisawa, H. Tsukiura, and H. Kawaguchi. 1978. Streptoalloteichus, a new genus of the family Actinoplanaceae. J. Antibiot. 31:497-510. 